\title{
片側性副鼻腔陰影を認めた手術症例の検討
}

\author{
藤崎 倫也, 兵 行義, 福島 久毅, \\ 原田保 \\ 川崎医科大学耳鼻咽喉科
}

近年好酸球性副鼻胿炎の増加やマクロライド療法の発達により, 副鼻腔陰影をきたす疾患の罹患率は変化し ていると報告されている。画像所見にて片側性副鼻腔陰影をきたす疾患は上顎洞癌の減少や，歯性感染症の認 識，歯科の治療方針により歯原性疾患の増加などが言われている。しかし近年では，片側性副鼻腔陰影をきた す疾患の頻度を明確にした検討の報告は少ない。そこで今回われわれは片側性副鼻腔除影をCT検査で指摘さ れ, 手術を行った症例を対象として, 疾患の頻度およびCT検查所見の特徴を後方視的に検討したので報告す る。2012年 1 月〜2014年 4 月の間に当院で手術を施行した症例の中で, 術前単純CT検查において片側性副鼻腔 陰影を認めた72例を対象とした。検討項目は, 骨破壊の有無, 上顎洞陰影, 骨肥厚, 鼻中隔弯曲の有無とした。 結果として72例中 68 例は術前診断と術後診断が一致し, 慢性副鼻胿炎, 歯性上顎洞炎, 副鼻胿真菌症, 鼻副鼻 胿乳頭腫の順に頻度は高かった。また10例に骨破壊を認め, 内訳として上顎洞癌 4 例, 悪性リンパ腫, 鼻腔癌, 副鼻胿真菌症, 歯原性粘液腫, 副鼻胿囊胞, 歯根襄胞がそれぞれ 1 例であった。骨破壊をきたす疾患は悪性腫 瘍だけでなく囊胞病変や骨浸潤性の感染症も鑑別に入れる必要がある。術前にCT検查を行い, 術前診断をした うえで手術を施行しており, 今回の検討でこれが重要であることを再認識でき, また術前単純CTを丁寧に読影 しCT所見を総合的に判断することにより鑑別できることが示唆された。

キーワード：片側性副鼻腔陰影，頻度，CT検査

\section{Review of Surgical Cases Presenting Unilateral Sinus Shadows}

\author{
Tomoya Fujisaki, Yukiyoshi Hyo, Hisaki Fukushima, Tamotsu Harada \\ Department of Otolaryngology, Kawasaki Medical School
}

Introduction: Unilateral sinus shadows can be observed in various diseases, including chronic sinusitis, odontogenic maxillary sinusitis, paranasal mycosis, and naso-sinus tumor. Because the appropriate treatment varies for each disease, the preoperative differential diagnosis is important and is usually made by computed tomography (CT). Here we review our surgical cases presenting unilateral sinus shadows to determine the accuracy of preoperative diagnoses used to guide initial treatment planning and to assess the frequency and characteristics of unilateral sinusitis based on CT findings, such as bone destruction, the density of soft tissue shadows, bone hypertrophy and the presence or absence of a deflected septum.

Methods: The records of 72 patients who were found to have unilateral sinus shadows on CT and underwent surgery between January 2012 and April 2014 were reviewed.

Results and Discussion: The postoperative diagnosis was chronic sinusitis in $25(34.7 \%)$ patients, odontogenic 
maxillary sinusitis in $14(19.4 \%)$, paranasal mycosis in $9(12.5 \%)$, papilloma of the nasal and paranasal sinuses in $7(9.7 \%)$, maxillary carcinoma in $4(5.6 \%)$, radicular cyst in $4(5.6 \%)$ patients, and other in $9(12.5 \%)$ patients. Soft tissue shadows with heterogeneous CT values were observed in $21(84.0 \%)$ of the patients with chronic sinusitis, $12(85.7 \%)$ of the patients with odontogenic maxillary sinusitis, and $9(100 \%)$ of the patients with paranasal mycosis. CT revealed bone hypertrophy in 20 of the 25 (80.0\%) patients with chronic sinusitis, 8 of the $14(57.1 \%)$ patients with odontogenic maxillary sinusitis, and all $9(100 \%)$ of the patients with paranasal mycosis. As the appropriate treatment varies for each disease, the preoperative differential diagnosis should be made based on each patient's medical history, complaints, and CT findings. We determined the frequency of several diseases associated with unilateral sinusitis based on CT findings.

Key words : unilateral sinus shadow, frequency, CT findings

（2015年8月31日受稿，2016年5月27日受理）

はじめに

近年好酸球性副鼻腔炎の増加やマクロライド療法の発 達により, 副鼻腔陰影をきたす疾患の罹患率は変化して いると報告されている。画像所見にて片側性副鼻腔陰影 をきたす疾患としては上顎洞癌の減少や, 歯原性疾患の 増加などが言われている。しかし，こうした傾向を反映 した形で, 片側性副鼻腔院影を認める例での各原因疾患 の割合を調べた報告はさほど多く認めない。そこで今回 われわれは, 片側性副鼻腔陰影をCT検査で指摘され手術 を行った症例を対象として, 疾患の頻度およびCT検査所 見の特徴を検討したので報告する。

\section{対象・方法}

2012年 1 月〜 2014年 4 月の間に当院で手術を施行した 症例の中で, 術前単純CT検査において片側性副鼻腔陰影 を認めた72例（14〜86歳，平均年齢55歳，男性41例，女 性31例）を対象に後方視的検討を行った。なお術後性上 顎囊胞は除外した。外来で術前検査として施行したCT所 見を用いて検討し, 術後診断は手術所見, 病理組織所見, 培養検査を総合的に判断した。副鼻腔真菌症は病理結果 で真菌が確認できたもの, もしくは術中に真菌塊を認め たものを副鼻腔真菌症と診断し, 当院口腔外科にて歯と の関連が指摘されたものを歯性上顎洞炎と診断した。

CT所見の検討項目としては, 全症例に対して骨破壊の 有無を, 慢性副鼻腔炎, 副鼻腔真菌症, 歯性上顎洞炎の 計48例に対して上顎洞陰影, 骨肥厚, 鼻中隔弯曲の有無 について検討した。
結果

1. 片側性副鼻腔炎の疾患別頻度（表 1)

片側性副鼻腔陰影を認めた72例の内訳は，慢性副鼻腔 炎25例 $(34.7 \%)$ ，歯性上顎洞炎14例 $(19.4 \%)$ ，副鼻腔真 菌症 9 例 $(12.5 \%)$, 鼻副鼻腔乳頭腫 7 例 $(9.7 \%)$, 歯根 囊胞 4 例 $(5.6 \%)$, 上顎洞癌 4 例 $(5.6 \%)$, 鼻腔癌 3 例 (4.3\%), 副鼻腔豪胞 2 例 $(2.8 \%)$, 線維性骨異形成症 1 例 $(1.4 \%)$, 歯原性粘液腫 1 例 $(1.4 \%)$, アレルギー性副 鼻腔真菌症 1 例 $(1.4 \%)$, 悪性リンパ腫 1 例（1.4\%）で あった。術前診断と術後診断が異なっていたのは合計 4 例であった。術前に慢性副鼻腔炎と診断したが術後病理 診断が乳頭腫であった症例が 3 例, 術前に上顎洞癌と診 断したが術後病理診断が悪性リンパ腫であった症例が 1 例であった。

表 1 片側性副鼻腔陰影を認めた72例の内訳

\begin{tabular}{lc}
\hline 疾患 & 症例数 $(\%)$ \\
\hline 慢性副鼻腔炎 & $25(34.7 \%)$ \\
歯性上顎洞炎 & $14(19.4 \%)$ \\
副鼻腔真菌症 & $9(12.5 \%)$ \\
鼻副鼻腔乳頭腫 & $7(9.7 \%)$ \\
歯根囊胞 & $4(5.6 \%)$ \\
上䫟洞癌 & $4(5.6 \%)$ \\
鼻腔癌 & $3(4.2 \%)$ \\
副鼻腔震胞 & $2(2.8 \%)$ \\
線維性骨異形成症 & $1(1.4 \%)$ \\
歯原性粘液腫 & $1(1.4 \%)$ \\
アレルギー性副鼻腔真菌症 & $1(1.4 \%)$ \\
悪性リンパ腫 & $1(1.4 \%)$ \\
\hline
\end{tabular}


2. CT所見の特徵

2.1 骨破壞について

72 例中 10 例に骨破壊を認め, 内訳として上顎洞癌 4 例, 悪性リンパ腫, 鼻腔癌, 副鼻胿真菌症, 歯原性粘液腫, 副鼻腔霊胞, 歯根襄胞がそれぞれ 1 例であった。全症例 の中で上䫈洞癌は 4 例あり，全例に骨破壊を認めた。ま た副鼻腔囊胞は, 前頭洞囊胞 1 例, 穊骨洞囊胞 1 例の計 2 例あり，骨破壊を認めたのは前頭洞囊胞であった。副 鼻腔真菌症については 9 例中 1 例に骨破壊を認め, 臨床 学的に浸潤型副鼻胿真菌症と診断した。

\section{2 上顎洞除影について（表 2)}

前述のとおり慢性副鼻胿炎, 副鼻脘真菌症, 歯性上顎 洞炎の計48例に対して検討を行った。上顎洞陰影が均一 であったものは慢性副鼻腔炎では21/25例（84.0\%），歯 性上顎洞炎では $12 / 14$ 例（85.7\%）であった。一方，副鼻 腔真菌症では上顎洞㓌影は9/9例（100\%）において不均 一であった。

\section{3 骨肥厚について (表 3 )}

患側と対側の比較で骨肥厚と判断した。副鼻腔真菌症 では9/9例（100\%)，慢性副鼻腔炎は20/25例（80.0\%）， 歯性上顎洞炎では8/14例（57.1\%）で骨肥厚を認めた。 2.4 鼻中隔弯曲について (表 4)

慢性副鼻胫炎では $9 / 25$ 例 $(36.0 \%)$ ，歯性上顎洞炎で 7/14例 (50.0\%), 副鼻胿真菌症に抒いては4/9例 (44.4\%)

表 2 炎症性疾患48例における上顎洞陰影について

\begin{tabular}{lcc}
\hline 疾患 & 均一 & 不均一 \\
\hline 慢性副鼻腔炎 (25例) & 21例 $(84.0 \%)$ & 4 例 $(16.0 \%)$ \\
歯性上顎洞炎 (14例) & 12 例 $(85.7 \%)$ & 2 例 $(14.3 \%)$ \\
副鼻腔真菌症 (9 例) & 0 例 $(0 \%)$ & 9 例 $(100 \%)$ \\
\hline
\end{tabular}

表 3 炎症性疾患48例における骨肥厚について

\begin{tabular}{lcl}
\hline 疾患 & あり & \multicolumn{1}{c}{ なし } \\
\hline 慢性副鼻腔炎 (25例) & 20例 $(80.0 \%)$ & 5 例 $(20.0 \%)$ \\
歯性上顎洞炎 (14例) & 8 例 $(57.1 \%)$ & 6 例 $(42.9 \%)$ \\
副鼻腔真菌症 $(9$ 例) & 9 例 $(100 \%)$ & 0 例 $(0 \%)$ \\
\hline
\end{tabular}

表 4 炎症性疾患48例における鼻中隔弯曲について

\begin{tabular}{cccc}
\hline 疾患 & なし & 患側凸 & 患側凹 \\
\hline 慢性副鼻腔炎 $(25$ 例 $)$ & 16 例 & 4 例 & 5 例 \\
歯性上顎洞炎 $(14$ 例 $)$ & 7 例 & 4 例 & 3 例 \\
副鼻腔真菌症 $(9$ 例 $)$ & 5 例 & 0 例 & 4 例
\end{tabular}

に鼻中隔弯曲を認め, 副鼻腔真菌症の鼻中隔弯曲側は全 例患側凹側であった。

\section{考察}

昨今, 好酸球性副鼻腔炎が増加し, 鼻内視鏡手術でも 両側性副鼻腔炎の頻度が増加している。片側性副鼻腔陰 影をきたす疾患においては，上顎洞癌の減少や歯原性疾 患の増加が言われて打り, 疾患の頻度は以前と変化して いる可能性が高い。そこで今回われわれは内視鏡手術を 施行した片側性副鼻腔症例について疾患別頻度を検討し た。また多くの検査を行うほど診断の感度，特異度は高 くなるが，時間や医療費においては患者のみならず医療 者に対しても負担が多い。そのことからCT検查所見の特 徴についても検討を行った。

片側性副鼻胿炎をきたす疾患別頻度として, 出島ら 内視鏡下鼻副鼻腔手術を施行した一側性副鼻腔炎症例 128例中，慢性副鼻腔炎77例（60.2\%），副鼻腔真菌症28 例 $(21.9 \%)$ ，上㖽洞性後鼻孔ポリープ17例 $(13.3 \%)$ ，ア レルギー性副鼻腔真菌症 6 例（4.7\%）であったと報告し ている。また吉田ら ${ }^{2)}$ は内視鏡手術を施行した片側性副 鼻腔炎169例の内訳として慢性副鼻腔炎99例（58.6\%), 副鼻腔真菌症29例 (17.2\%), 歯性上顎洞炎23例 (13.6\%), 上顎洞性後鼻孔ポリープ15例 $(8.9 \%)$ ，アレルギー性副 鼻腔真菌症 3 例 $(1.8 \%)$ と報告している。出島, 吉田の 報告では腫瘍の頻度が記されておらず，西田 ${ }^{33}$ は一側性 副鼻腔疾患27例の中で腫瘍性疾患が15例（56.0\%）と高 率であったと報告しており，腫瘍性病変の有無が若干の 頻度の差に影響していることが予測される。今回の検討 では術後診断で慢性副鼻腔炎, 歯性上顎洞炎, 副鼻腔真 菌症，鼻副鼻胿乳頭腫の順に頻度は高く，多施設の報告 と比較し慢性副鼻腔炎, 副鼻腔真菌症は少なく, 歯性上 顎洞炎が多い結果であった。

歯性上顎洞炎は未治療の歯が発生に関与していること はまれであり，不十分な根管治療による根管性歯周炎が

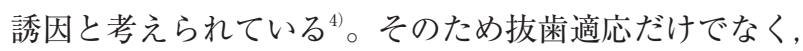
歯性感染症の認識や歯科の治療歴が有病率に関与してい ると考えられる。われわれは片側性副鼻腔炎を認めた 際，動摇歯や吒打痛などの身体所見をまず確認してい る。そこで歯原性疾患を疑った際はパノラマX線撮影や, CT所見にて歯根周囲の状態を確認するように心がけ, 必 ず口腔外科に相談している。片側性化膿性副鼻腔炎と診 断しがちであるが, 歯性上顎洞炎や歯根囊胞などを念頭 に入れて診察することで，当科では歯原性疾患の頻度が 多いように考える。

副鼻胿は粘骨膜を介して骨壁に囲まれており，副鼻胫 
の炎症は粘膜だけでなく骨壁にも影響を与えるといわれ ている5)。そのため副鼻垫炎や鼻副鼻腔腫瘍ではCT検査 が疾患の鑑別に広く用いられている。CT画像で骨破壊 の有無は悪性腫瘍の鑑別に重要な所見であり, 片側性副 鼻脉陰影を認めた全症例において骨破壊の有無について 検討を行った。上顎洞陰影, 骨肥厚の有無は炎症性疾患 で鑑別に有用であり，今回疾患の頻度が高かった慢性副 鼻胫炎, 副鼻垫真菌症, 歯性上顎洞炎の 3 症例において 各々検討した。また発症および遷延化に影響する因子と して鼻中隔弯曲の影響が言われていることから，上記の 3 疾患において鼻中隔弯曲の有無についても検討を 行った。

森田 ${ }^{6}$ は上顎洞真菌症 22 例中 2 例で骨破壊を認め, 2 例 とも上顎洞内側壁の骨破壊であり, Hora ${ }^{7}$ の分類は全例 非浸潤型副鼻空真菌症であったと報告している。今回の われわれの検討では副鼻腔真菌症 9 例中 1 例で骨破壊を 認めていたが, 臨床的に浸潤型副鼻腔真菌症と診断して いる。残りの 8 例は慢性非浸潤型副鼻胿真菌症と診断し ており，全例で骨破壊は認めなかった。また慢性副鼻腔 炎，歯性上顎洞炎に打いて骨破壊は 1 例も認めず，上顎 洞癌では全例で骨破壊を認めていた。扁平上皮癌は広範 囲な骨破壊を特徴としているが，上顎洞の中でも腺癌は 骨破壊だけではなく，真菌症のように石灰化を伴う不均 一な陰影をきたすと言われており ，鑑別が重要である。

副鼻胫真菌症はCT上, 高吸収域と低吸収域が混在する モザイク像や，真菌が産生するリン酸カルシウムや硫酸 カルシウムの集積による石灰化像が特徴)と言われてお り, 今回の検討でも全例で上顎洞陰影は不均一であった。 慢性副鼻腔炎や歯性上顎洞炎では $80 \%$ 程度の症例で均一 であったが，20\%では不均一であった。それらの症例で は副鼻腔真菌症と鑑別が困難な場合があり, 総合的な判 断が必要である。

CT検查での骨肥厚の原因として加瀬ら ${ }^{10)}$ は，骨壁の実 際の肥厚と, CT值の高い組織のアーチファクトによる 影響があると推測している。骨髄質の緻密化により皮質 層が厚みを增すことによる硬化像と, 皮質, 髄質, 煩骨 組織の増量による副鼻腔骨壁が求心的に厚みを増した硬 化像に大別される ${ }^{11)}$ 。大平ら ${ }^{8}$ は慢性副鼻胿炎では長期間 の炎症性刺激により炎症性の骨增殖が起こり, 急性副鼻 腔炎では炎症性刺激が短期間であり骨変化が起こらない と仮定している。また副鼻腔真菌症では真菌のアミノ酸 代謝により生じる鉄やマンガンなどの重金属やカルシウ ムの存在により骨肥厚を認めると報告している。一方 アーチファクトによる骨肥厚は上顎洞内の粘膜や膿汁な どのX線吸収物質が上顎洞壁に影響を与えると言われて
いる ${ }^{12)}$ ここを回避する方法として，CT画像において骨 肥厚を判断する際には骨組織条件を用いることが重要と 考えられており，今回われわれは骨組織条件を使用し評 価を行った。堀部ら ${ }^{5}$ によると, 副鼻腔真菌症は上顎洞後 壁の $80 \%$ で骨肥厚を認め, 骨密度も健側に比べ優位に増 加しており, 慢性副鼻胫炎では上顎洞後壁は $30 \%$ の症例 で骨肥厚を認めたが，骨密度は健側と有意差はなかった と報告している。今回の検討において慢性副鼻腔炎では $80 \%$, 歯性上顎洞炎では $57 \%$ も症例に骨肥厚を認め, 副鼻胫真菌症では全例で骨肥厚を認めた。

我々の検討において, 副鼻腔真菌症 9 例中 4 例に鼻中 隔弯曲を認め, 全例患側凹側の罹患であった。北ら ${ }^{13}$ の 報告も同様, 鼻中隔弯曲を認めた副鼻腔真菌症23例中, 患側凸側 9 例 $(39 \%)$, 患側凹側14例（61\%）と患側凹側 に多い結果であった。副鼻腔真菌症は呼吸に伴って鼻副 鼻腔に真菌が侵入したことによって起こる疾患であり， 患側凹群の真菌吸入量が多いことが影響していると考え る。空気流入量は上顎洞, 蝶形骨洞, 節骨洞, 前頭洞の 順に多く, 今回の副鼻胿真菌症 9 例では全症例で上顎洞 は䍜患していた。慢性非浸潤型副鼻腔真菌症 8 例中CT 検査で上顎洞以外に陰影を認めていた例は 2 例あり，い ずれも上顎洞以外からは真菌は検出されなかった。蝶形 骨洞真菌症は副鼻腔真菌症の中でも5-10\%程度 ${ }^{14,15)}$ と頻 度が低いと報告されており，今回の検討でも認めていな い。慢性炎症や, 線毛細胞の機能の低下が生じていた場 合, 含入された空気の分生子, 胞子の増殖は容易である ${ }^{16}$ と言われており，上顎洞ではOMC (ostio-meatal-complex) の閉鎖や上顎洞自然口の狭小化により洞内の換気不全が 生じ, 真菌による炎症が波及し, 線毛細胞の遊走能の低 下が起こり,さらなる真菌の増殖を引き起こすと考える。 慢性副鼻腔炎ではマクロライド少量長期投与が多用 され，保存的治療で軽快する例が増えてきた。ただ無効 例，効果不十分例も多くみられ，それらの疾患に対して は手術が必要である。慢性副鼻腔炎における鼻中隔弯曲 の影響を検討したが，有意差は認めなかった。以前の報 告でも, 慢性副鼻腔炎においては鼻中隔弯曲が病因であ るかは明確には分からないとColletら ${ }^{17}$ は報告しており， Harar ${ }^{18}$, Y $a s a n{ }^{19}$ らも鼻中隔弯曲症患者と非鼻中隔弯曲 症患者における慢性副鼻腔炎の発現には有意差がないと 言及している。慢性副鼻腔炎の発現には鼻中隔弯曲の程 度による差も考えられる為, 今後症例数を増やしOMCの 閉鎖なども項目に入れ検討したい。

今回のわれわれの検討では72例中 68 例で術前診断と術 後診断は同じであった。術前に慢性副鼻腔炎による鼻咠 と診断していたが, 術後病理組織診断では鼻副鼻脉乳頭 

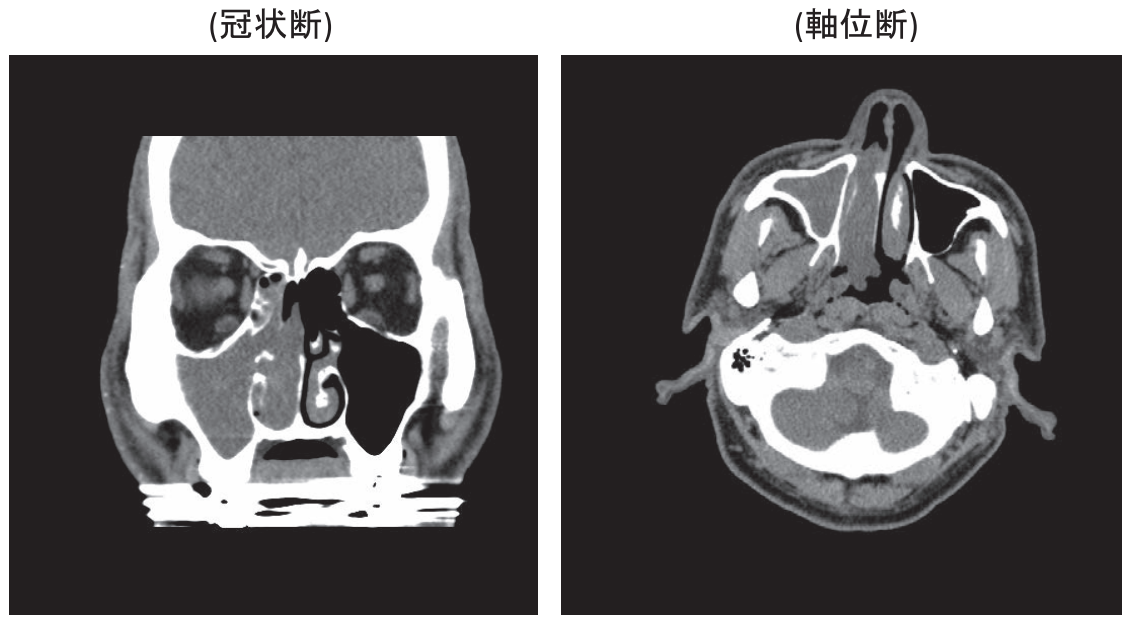

図 1

(T1)

(T1 造影)

(STIR)

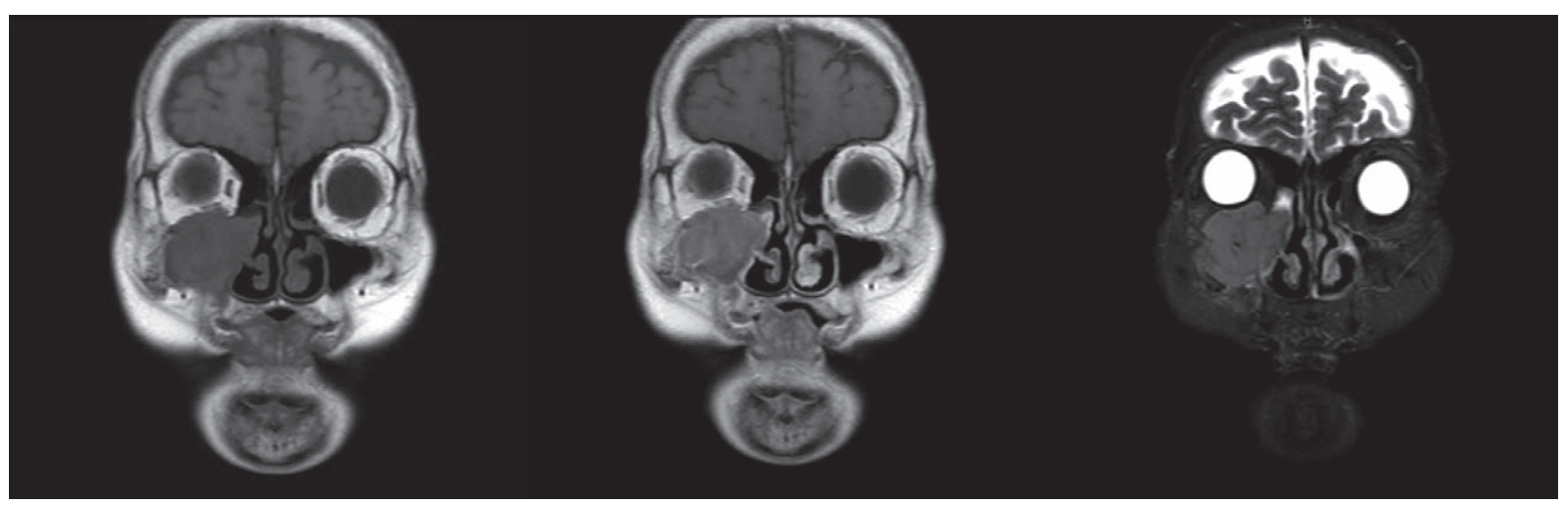

図2

(単純冠状断)

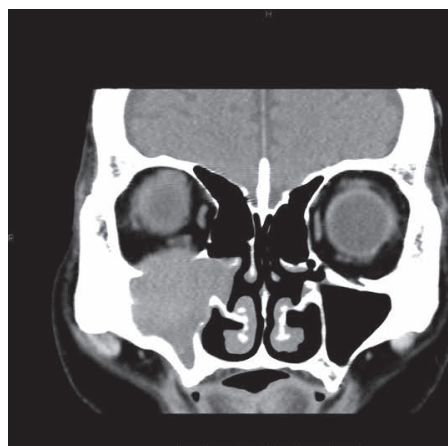

(骨条件冠状断)

(骨条件 軸位断)

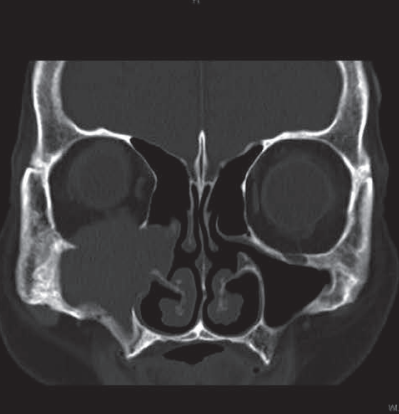

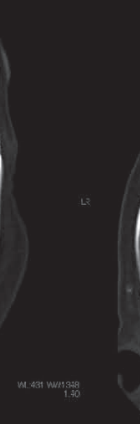

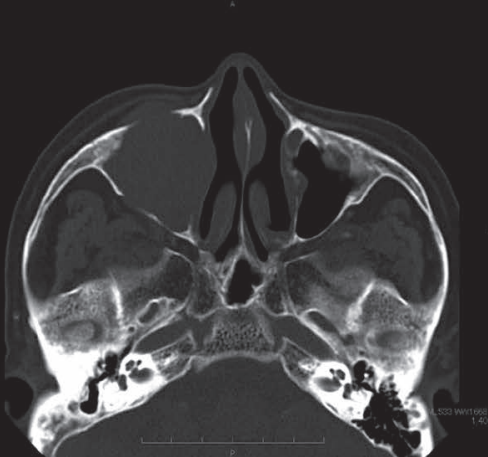

図3

腫であった例が 3 例あり,これらは局所所見およびCT画 像のみでは鑑別が困難であった。その際の鑑別にはCT検 查だけでなくMRI検査の画像検査も有用である。
当科にて手術を施行した片側性副鼻腔病変について炎 症性疾患を中心に画像検査の有効性について検討した。 術前診断を行う上で画像検査は必須であり，画像所見を 
総合的に検討することにより診断に至ることが必要であ ると示唆された。

\section{まとめ}

1 ） CT検査で片側性副鼻腔陰影を認めた72例について, 疾患の頻度およびCT検査所見の特徴を後方視的に検 討した。

2 ） 72 例中68例で術前診断と術後診断が一致し, 慢性副 鼻腔炎, 歯性上顎洞炎, 副鼻腔真菌症, 鼻副鼻腔乳頭 腫の順に頻度は高かった。

3 ）術前診断を行う上で画像検査は必須であり, 画像所 見を総合的に検討することにより診断に至ることが必 要であると示唆された。

\section{参考文献}

1 ）出島健司，松本幸江，板東秀樹，他：一側性副鼻腔 炎症例の臨床検討一アレルギー性真菌性鼻副鼻腔炎 に着目して一。耳鼻咽喉科臨床 $2011 ； 104 ： 17-22$.

2 ）吉田拓人, 浅香大也, 中山次久, 他 : 片側性副鼻腔 炎の自覚症状についての検討.耳展 2012 ; 55 ：434439 .

3 ）西田吉直, 内藤 泰, 本庄 嚴：一側性副鼻腔疾患 のCT像. 耳鼻臨床 $1990 ; 83: 741-745$.

4 ）佐藤公則：歯性上顎洞炎の病態と内視鏡下鼻内手術 の有用性. 日耳鼻 $2001 ; 104: 715-720$.

5 ）堀部よし恵, 田口 明，佐藤考至，他：真菌性上顎 洞炎の骨硬化像の検討. 耳鼻臨床 1998;91:353-360.

6 ）森田倫正, 福島久毅, 秋定 健, 他：上顎洞真菌症 22例の臨床的検討. 耳鼻臨床 $2003 ; 96$ : 127-132.

7 ) Hora JF : Primary aspergillosis of the paranasal sinuses and associated areas. Laryngoscope 1965 ; $75: 768-773$.
8 ）大平真司，有賀秀治，石田 稔：一側性副鼻腔疾患 のCT像. 日耳鼻 $1985 ; 88: 1040-1044$.

9 ) Dhong HJ, Jung JY, Park JH : Diagnostic accuracy in sinus fungus balls: CT scan and operative findings. Am J Rhinol $2000 ; 4: 227-231$.

10）加瀬康弘, 北原伸郎, 堀内康治, 他:CTにおける上 顎洞肥厚像の検討. 日耳鼻 $1988 ； 91 ： 547-552$.

11）飯沼壽孝:副鼻腔疾患の骨変化一画像からの考察一. 耳喉頭頸 $1995 ； 67 ： 942-953$.

12）西川益利：片側性副鼻腔炎症例におけるCT-scan像 と歪み一上顎洞後壁骨肥厚像の検討とファントーム 実験一. 日耳鼻 $1981 ； 84 ： 408-412$.

13）北 秀明, 朝倉光司, 石川忠考, 他：鼻副鼻腔真菌 症の臨床的検討。耳鼻臨床 $1999 ； 92 ： 151-155$.

14）佐伯忠彦, 竹田一彦, 白馬信洋, 他：副鼻腔真菌症 の臨床的検討. 耳鼻臨床 $1996 ； 89 ： 199-207$.

15）犬山征夫, 小津雷助, 堀内正敏, 他：副鼻腔真菌症 に関する臨床的観察。耳鼻臨床 1999 ; 69 :325-335.

16）石倉武雄，河村正三，岡田博允，他：真菌症上顎洞 炎の臨床的並びに病理組織学的所見. 日耳鼻 1969 ; $72: 857-867$

17) Collet $\mathrm{S}$, Bertrand $\mathrm{B}$, Cornu $\mathrm{S}$, et al : Is septal deviation a risk for chronic sinusitis? Review of literature. Acta Otorhinolaryngol Belg 2001 ; 55 : 299-304.

18) Harar RP, Chadha NK, Rogers G: The role of septal deviation in adult chronic rhinosinusitis-a study of 500 patients-. Rhinology 2004 ; 42 : 126-130.

19) Yasan H, Doğru H, Baykal B, et al : What is the relationship between chronic sinus disease and isolated nasal septal deviation? Otolaryngol Head Neck Surg $2005 ; 133$ : 190-193. 